\section{artelogie}

\section{Artelogie}

Recherche sur les arts, le patrimoine et la littérature de I'Amérique latine

\section{$11 \mid 2017$}

Délocalités, translocalités et activisme dans l'art électronique et biomédiale latino-américain

\title{
Video 4 - Deslocalizaciones y arte digital.
}

Pat Badani entrevista a Rafael Lozano Hemmer (4)

\section{Pat Badani y Rafael Lozano Hemmer}

\section{(2) OpenEdition \\ Journals}

Edición electrónica

URL: http://journals.openedition.org/artelogie/1655

DOI: 10.4000/artelogie. 1655

ISSN: 2115-6395

\section{Editor}

Association ESCAL

Referencia electrónica

Pat Badani y Rafael Lozano Hemmer, « Video 4 - Deslocalizaciones y arte digital. », Artelogie [En línea], 11 | 2017, Publicado el , consultado el 15 septiembre 2020. URL : http://journals.openedition.org/ artelogie/1655

Este documento fue generado automáticamente el 15 septiembre 2020.

Association ESCAL 


\section{Video 4 - Deslocalizaciones y arte digital.}

Pat Badani entrevista a Rafael Lozano Hemmer (4)

Pat Badani y Rafael Lozano Hemmer

Este medio no se puede ver aquí. Por favor refiérase a la edición en línea http:// journals.openedition.org/artelogie/1655 